\title{
The influence of internal migration on male earnings in Brazil, 1970-2000
}

\author{
Ernesto F. L. Amaral \\ RAND Corporation \\ eflamaral@gmail.com \\ Eduardo L. G. Rios-Neto \\ Universidade Federal de Minas Gerais, Brazil \\ eduardo@cedeplar.ufmg.br \\ Joseph E. Potter \\ The University of Texas at Austin \\ joe@prc.utexas.edu
}

\begin{abstract}
This paper deals with the impact of internal migration flows on the earnings of male workers. The availability of jobs and income levels in sending and receiving areas also influence internal population flows. Thus, migration is an endogenous variable that cannot be simply introduced as an exogenous variable when estimating labour outcomes. A methodological approach is developed to introduce migration into our models, dealing with the issue of reverse causality between migration and earnings. We implement this strategy using the 1970-2000 Brazilian Demographic Censuses. Our findings reflect our initial hypothesis, indicating that migration flows have a negative impact on male earnings, when considering cohort size as a factor. A ten percent increase in migration rates would have reduced the wages of competing workers by up to three percent in 2000. These methodological strategies can be applied to other countries that have similar available migration data. Public policies should take into account the levels of inand out-migration flows in specific locations, in order to stimulate economic development in these areas.

\section{Keywords}

Internal migration. Earnings. Labour market. Reverse causality. Migration schedules.

\section{Acknowledgments}

This research received support from the Brazilian Association of Population Studies (Associação Brasileira de Estudos Populacionais - ABEP) and the Brazilian Institute of Applied Economic Research (Instituto de Pesquisa Econômica Aplicada - IPEA), through a research scholarship on Demographic Dynamics and Brazilian Development in the Long Term (Dinâmica Demográfica e o Desenvolvimento Brasileiro de Longo Prazo, ABEP/IPEA, 001/2009). We would like to thank Adriane Reams for editing this paper.
\end{abstract}

\section{Final publication}

Amaral EFL, Rios-Neto ELG, Potter JE. 2016. "The influence of internal migration on male earnings in Brazil, 1970-2000." Migration and Development, 5(1): 55-78. (http://dx.doi.org/10.1080/21632324.2015.1038010) 


\section{Introduction}

This paper analyses the relationship between internal migration flows and earnings of male workers. Recent studies have been dealing with the impact of migration on local labour market outcomes (Berker 2011; Boustan et al. 2010). However, migration flows cannot be introduced as independent variables in the models (Muth 1971). Internal population flows are influenced by the availability of jobs and income levels in sending and receiving areas. Thus, migration is an endogenous variable that cannot be simply utilized as an exogenous variable when estimating labour outcomes. This paper deals with this endogeneity issue in the context of internal population streams and their influence on the level of earnings.

The study of internal migration determinants dates back to classical economic development theory, where migration is considered to be a mechanism that establishes regional spatialeconomic equilibrium (Ravenstein 1885, 1889). Migrants move from low income to high-income areas and from densely to sparsely populated areas. Population streams are expected to occur between the poorest and wealthiest places and countries. Migration decisions are determined by "push" and "pull" factors in areas of origin and destination. Intervening obstacles (such as distance, physical barriers, immigration laws), as well as personal factors also influence migration flows (Greenwood et al. 1991; Lee 1966; Passaris 1989). Economic, environmental, demographic, and economic factors are assumed to drive migrants away from their places of origin and attract them to new places of destination. Although there are limitations in regards to the "push-pull” models (de Haas 2007, 2009; McDowell and de Haan 1997), this concept is still popular in migration literature.

Based on the regional equilibrium framework, distance is expected to play an intervening role on the levels of population streams. Previous studies took the distances between areas into 
account by utilizing gravity models to estimate migration flows (Head 2000; Lowry 1966;

Poyhonen 1963; Tinbergen 1962). Gravity models address the distance between areas, as well as the changing population in the areas over time. The idea behind these models is to use the distance between areas and population trends to estimate the level of migration between areas. Distance is constant over time, but population growth affects the out- and in-migration trends of different regions.

Several studies have analysed the impact of international migration on earnings in recent decades. Different approaches were implemented to compare employment opportunities between immigrants and natives across regions. These studies reflect varying results, depending on the countries, methods, unit of analysis, and data utilized. What matters for our study is that immigration reduces the wage and labour supply of competing native workers (Borjas 2003). Wages decreased between a three and four percent for a ten percent increase in the labour supply (Borjas 2003).

Other studies indicate that natives experience occupational upgrading and specialization, as an adjustment to immigration flows (Foged \& Peri, 2015). While immigrants tend to concentrate on manual jobs, due to language and cultural limitations, natives leave their previous occupations to work on more complex jobs. This pattern generates improvements in natives' wages and mobility, without negative effects on unemployment for unskilled natives. Countries with larger immigrant competition experience a move of native workers to more sophisticated skills with higher incomes, which require higher education levels (Cattaneo, Fiorio \& Peri, 2013). Natives engage in entrepreneurial activities in response to larger immigrant competition. Open immigration policies tend to generate better career opportunities for natives, when combined with flexible labor markets (Peri, 2014). Due to data limitation, we are going to examine only the 
short-term effects of migration flows on earnings, in a similar exercise conducted by Borjas (2003).

As a strategy for dealing with the simultaneity issue, generated by the two-way causality between migration flows and levels of earnings, we have developed a new methodological procedure. We implement our proposition to analyse the relationship between internal migration flows and earnings of male workers in Brazil between 1970 and 2000. We hypothesise that migration flows have a negative impact on earnings. Internal migration is an important demographic component in the country. Significant population streams from rural to urban areas were significant to the urbanization process of the country in previous decades. Since the 1970s, urban-urban migration flows have become more prominent (Amaral 2008; Baeninger 2000; Brito et al. 2001; Brito and Carvalho 2006; Cunha 2006; Cunha and Baeninger 2000). There are multiple internal migration flows, some reflecting older patterns (from the Northeast to the Southeast region), as well as the establishment of new areas of origin and destination (suburbs of large cities, medium-sized cities, and returning migrants) (Amaral 2013; Braga and Rezende 2010; Lima and Braga 2010; Matos 2005a, 2005b; Matos and Soares 2009). There is also evidence that recent migrants are usually more educated than in previous decades (Baeninger 2000; Braga and Rezende 2010; Cunha and Baeninger 2000; Golgher 2008; Golgher and Marques 2009; Rigotti 2006).

The availability of jobs and the level of earnings are major factors influencing internal migration flows in Brazil (Oliveira and Jannuzzi 2005). People move to areas with better income opportunities due to relative declines in the size of the labour force in a particular age and education group. If there were no migration flows, the sending areas (which already have lower relative earnings) would have even lower earnings, and the receiving areas (which already have 
higher relative earnings) would experience an increase in earnings. Internal migration is characterized by streams from areas with higher rates of fertility to those with lower rates of fertility. These migration streams might reduce the differential in birth rates among the different areas. However, this process might also increase the difference in dependency ratios, since migrants are concentrated within working ages. Since our models are estimated at the local level, these specificities indicate that we have to take into account migration rates to understand the levels and trends of earnings in the country. Thus, we need to estimate exogenous measures of population streams, to include in the models that estimate earnings.

Our study follows six major methodological steps to estimate exogenous migration. (1) Estimation of the influence of internal migration on labour market outcomes (Berker 2011; Borjas 2003; Boustan et al. 2010). (2) Estimation of the exogenous level of migration (gravity models) (Head 2000; Lowry 1966; Poyhonen 1963; Stillwell 2009; Tinbergen 1962). (3) Estimation of the exogenous age pattern of migration (Amaral 2008). (4) Modelling of the exogenous age pattern of migration (Raymer and Rogers 2007; Rogers and Castro 1981; Rogers and Jordan 2004). (5) Integration of the exogenous level (step 2) and age pattern (step 4) of migration. (6) Calculation of a measure of the force of migration for each area. We introduced these new rates as an exogenous measure of migration into the earnings equations (step 1).

This paper is organized into three main sections, following this introduction. First, there is a detailed presentation of data and our six methodological steps. Then we present our main findings. The final section summarizes our final considerations. This study provides a methodological approach for generating exogenous measures of migration that can be implemented with data from other countries. 


\section{Methods}

\subsection{Data and unit of analysis}

Microdata from the 1970, 1980, 1991, and 2000 Brazilian Demographic Censuses were used to estimate the impact of population flows on the earnings of male workers at the local level over time. For this paper, information on age was categorised into four groups: youths (15-24 years-of-age); young adults (25-34 years-of-age); experienced adults (35-49 years-of-age); and older adults (50-64 years-of-age). The level of education was classified into three groups using information on completed years of schooling: no further than the first phase of elementary school (0-4 years of schooling); second phase of elementary school (5-8 years of schooling); and at least some secondary school (9 years of schooling or more).

We have the same Census information for each micro-region about the age-education structure of the female workforce and migrants as we do for males. However, the distributions of female workers and migrants by age and education are highly correlated with those of male workers. The way in which the exclusion of women from the equations biases the coefficients for male workers depends on the relationships between male and female workers and migrants. There is no evidence about these biases. Thus, this possible bias is an empirical issue. Previous estimates (not shown) added women to the models. The general results did not differ from the ones presented in this paper. However, the correct inclusion of women in the models would require the estimation of exogenous measures of women in the labour market, as well as in the population flows. Since this estimation is not the aim of this study, we decided to focus the analysis on males.

For this study, information on state of birth and on the number of years that the respondent lived in the municipality was obtained from the 1970, 1980, 1991, and 2000 Demographic 
Censuses. Furthermore, the 1991 and 2000 Censuses were used to provide information on which municipality and state the person lived in exactly five years before the Census. Information on state of birth is a way to measure lifetime migrants by identifying people born in a different state. The number of years that the respondent lived in the municipality generates information on recent migration transitions, because we can estimate how many people lived for less than five years in the current municipality (time of residence). Finally, information on residence five years before the Census also provides estimations of recent migration flows.

In-migration rates were calculated for each one of the 502 Brazilian micro-regions (groups of municipalities) by age-education group and year. These 502 micro-regions differ from those defined by the Brazilian Institute of Geography and Statistics (IBGE) and available in the Census microdata, but closely approximate those that are defined in the 1991 Census (Potter et al. 2002).

\subsection{Estimating the influence of internal migration on earnings}

In order to measure the effect of internal migration on labour market outcomes (Berker 2011; Boustan et al. 2010), the dependent variable was developed as the natural logarithm of the mean of the real monthly earnings based on primary occupation for each year, micro-region, and age-education group.

In Equation (1), $\log \left(Y_{g i t}\right)$ is the logarithm of wages. Twelve indicators of age-education groups $(G)$ interacting with time $(\theta)$ are included in the model, establishing the first ageeducation group interacting with time (four variables) as the reference category. Thus, $G$ is a set of age-education-group indicators (dichotomous variables): $G_{11}$ (15-24 years-of-age; 0-4 education), $G_{12}(15-24 ; 5-8), G_{13}(15-24 ; 9+), G_{21}(25-34 ; 0-4), G_{22}(25-34 ; 5-8), G_{23}(25-34$; 9+), $G_{31}(35-49 ; 0-4), G_{32}(35-49 ; 5-8), G_{33}(35-49 ; 9+), G_{41}(50-64 ; 0-4), G_{42}(50-64 ; 5-8)$, 
and $G_{43}(50-64 ; 9+)$. In order to evaluate the impact of migration flows on earnings, a set of 48 variables were added to the model, with information on migration rates categorized by ageeducation groups $(M)$, as they interact with time $(\theta)$. The model considers 502 micro-regions $(i)$, four Censuses $(1970,1980,1991$, and 2000) $(t), 12$ age-education groups $(g)$, and 2,008 (502*4) area-time-fixed effects $(\alpha)$ :

$\log \left(Y_{\text {git }}\right)=\beta_{0}+\left(\beta_{1} G_{12}+\cdots+\beta_{11} G_{43}\right) * \theta_{t}+\left(\delta_{1} M_{11}+\cdots+\delta_{12} M_{43}\right) * \theta_{t}+\alpha_{i t}+\varepsilon_{\text {git }}$.

Not only do migration flows have a significant impact on earnings, but demographic and educational changes also generate variation in cohort size and, thus, influence various aspects of the labour market. Earnings of male workers appear to be significantly influenced by the ageeducation composition of the workforce, i.e., large cohorts do depress earnings (Amaral et al. 2013; Berger 1985; Biagi and Lucifora 2008; Brunello 2010; Easterlin 1978; Freeman 1979; Katz and Autor 1999; Katz and Murphy 1992; Korenman and Neumark 2000; Korpi 2008; Mansour 2010; Moretti 2004; Sapozhnikov and Triest 2007; Shimer 2001; Skans 2005; Welch 1979). As a strategy to estimate the impact of cohort size on earnings, the distribution of the male population in our 12 age-education groups $(X)$, interacted with time $(\theta)$, can be introduced as a set of 48 variables:

$$
\begin{aligned}
& \log \left(Y_{\text {git }}\right)=\beta_{0}+\left(\beta_{1} G_{12}+\cdots+\beta_{11} G_{43}\right) * \theta_{t}+\left(\delta_{1} M_{11}+\cdots+\delta_{12} M_{43}\right) * \theta_{t}+ \\
& \left(\gamma_{1} X_{11}+\cdots+\gamma_{12} X_{43}\right) * \theta_{t}+\alpha_{i t}+\varepsilon_{g i t} .
\end{aligned}
$$

Because Brazil was divided into 502 micro-regions, 12 age-education groups, and four censuses, the maximum possible number of observations for the regressions is 24,096 . However, only cells with at least 25 observations are included in the estimations, in order to minimize potential problems of heteroskedasticity. The maximum number of observations was reduced to 
19,727 for models that used the $1970,1980,1991$, and 2000 Censuses, and to 10,782 for models with only data from 1991 and 2000.

Although these models express the effect of migration flows on earnings, internal population flows in Brazil are influenced by the availability of jobs and income levels in sending and receiving areas. In order to correct for this simultaneity problem, a new methodology was developed by congregating the migration level estimate (Stillwell 2009) to the estimate for the age pattern of migration (Rogers and Castro 1981). This methodological strategy is explained in the following subsections.

\subsection{Estimating the exogenous level of migration}

The first step to correct migration information and introduce it as an exogenous variable in our models is to estimate gravity models (Head 2000; Lowry 1966; Poyhonen 1963; Tinbergen 1962), which take into account distances among areas as an instrumental variable. More than just distance, these gravity models consider the population in the area of origin (at the beginning of the period), the population in the area of destination (at the end of the period), the proportion of migrants already living in a specific area, and time (dependent variable). Distance is constant over time, but the population at the beginning and end of the period in each area has varying outand in-migration trends over time.

Poisson statistical regressions can generate gravity models for inter-regional migration flows, with a dependent variable measured in discrete units (integer counts of migrants) and a discrete probability distribution (Stillwell 2009). These models are appropriate for our purposes, because they do not maintain error variances as constant for the different sizes of estimated flows, as is the case of "log-normal" models. In the case of migration flows between the 502 
Brazilian micro-regions, the Poisson model is also recommended because there are a significant number of smaller flows among the areas, as well as a small number of larger migration flows. The Poisson regression equation is:

$M_{i j}=\exp \left(b_{0}+b_{1} \log P_{i}+b_{2} \log P_{j}+b_{3} \log d_{i j}\right)+\varepsilon_{i j}$

where $M_{i j}$ represents migrants at the end of the period between areas of origin $(i)$ and destination $(j)$; $b_{0}$ is the constant; $b_{1}$ is the regression coefficient associated with the population at the beginning of the period $\left(P_{i}\right) ; b_{2}$ is the coefficient associated with the population at the end of the period $\left(P_{j}\right) ; b_{3}$ is related to the distance between micro-regions $\left(d_{i j}\right)$; and $\varepsilon_{i j}$ is the random error term associated with all pairs of micro-regions.

To estimate Equation (3), it is necessary to obtain information about the population at the beginning of the migration period $\left(P_{i}\right)$, as well as at the end of the period $\left(P_{j}\right)$. Because migration flows between the Brazilian micro-regions $(502 * 501=251,502$ flows $)$ have a small number of migrants in several cases, a group with a high level of migration among all age groups has to be selected. People between 20 and 24 years-of-age have the highest rates of migration (Rogers and Castro 1981). Thus, this group was used to estimate migration flows between micro-regions $\left(M_{i j}\right)$, as well as to calculate the population exposed to the risk of migration at the beginning of the period $\left(P_{i}\right)$ and end of the period $\left(P_{j}\right)$.

In order to generate these flows, it is necessary to use migration information that indicates the micro-region (or municipality) of residence at a specific previous moment. Information about the municipality of previous residence (whether the person has lived for less than 10 years in the present municipality) is included in the 1980 and 1991 Censuses. Information about the municipality of residence five years before the Census, was collected in 1991 and 2000. Because one of the objectives of our estimates is to develop a methodology that can generate comparative 
results over time and can be used in future studies, this analysis used information on municipality of residence five years before the 1991 and 2000 Censuses. This migration information allowed the estimation of: (1) the population at the beginning of the period with 15-19 years-of-age by micro-region of origin, sex, and education group $\left(P_{i}\right) ;(2)$ the population at the end of the period with 20-24 years-of-age by micro-region of destination, sex, and education group $\left(P_{j}\right)$; and (3) migrants at the end of the period with 20-24 years-of-age by micro-region of both origin and destination, sex, and education group $\left(M_{i j}\right)$. Technically, the number of people who died between 1986 and 1991, as well as between 1995 and 2000, should have been estimated in order to consider them as members of the population at risk of migrating. However, we did not calculate these deaths, based on the assumption that the 20-24 age group used for this analysis has a low mortality rate, which does not compromise the estimated results. Using 2000 data for Brazilian males from the Latin American Human Mortality Database (Piedad Urdinola and Queiroz 2013), the estimated mortality rates are: 1.655 deaths per 1,000 inhabitants (15-19 years-of-age); 2.673 deaths (20-24); 2.890 deaths (25-29); 3.270 deaths (30-34); 3.971 deaths (35-39); 5.251 deaths (40-44); 7.096 deaths (45-49); 9.685 deaths (50-54); 13.999 deaths (55-59); and 19.962 deaths $(60-64)$.

This study used a matrix of kilometre distances between all Brazilian micro-regional centroids (http://schmert.net/KnoxCox), in order to estimate the $d_{i j}$ component of Equation (3). A combination of this matrix with information about the population size of micro-regions, as well as the age and education of migrants was used to generate attraction and repulsion measures of population flows among micro-regions.

More specifically, a dataset was organized containing information on: (1) micro-region of origin; (2) micro-region of destination; (3) kilometre distances between micro-regions $i$ and $j$; (4) 
population aged 15-19 years at the beginning of the period by sex, education group, and microregion of origin (1991 and 2000 Censuses); (5) population aged 20-24 years at the end of the period by sex, education group, and micro-region of destination (1991 and 2000 Censuses); and (6) migrants aged 20-24 years at the end of the period by micro-region of origin and destination, sex, and education group (1991 and 2000 Censuses). The logarithm of the variables was calculated before the estimation of Poisson regressions. The cells with no migration flows, or no population, were replaced by zero in the regression. Regressions were estimated for only the cases in which the micro-regions of origin were different than the micro-regions of destination, and for men. The results of these models by year and education groups are presented in Table 1 . The coefficients suggest that populations at the beginning and end of the period have a positive effect on migration rates, and distance has a negative impact on the dependent variable.

\section{>> Table $1<<<$}

Based on the coefficients of Table 1, male migrants between 20-24 years-of-age were predicted by year and education group in each micro-region of destination (at the end of the period). The migration rates for each combination of micro-region of origin and destination were calculated by year and education group, since the migration level is later used to estimate the effects of population flows on the earnings of workers at the end of the period.

After the estimation of the migration level among the micro-regions, it is necessary to estimate the age pattern of the migration rates for these areas. The following sub-sections explain the methodology used to estimate and model migration schedules, which determine the age patterns of population streams.

\subsection{Estimating the exogenous age pattern of migration}


The estimation of migration schedules provides information on the age patterns of population flows. These schedules require the use of age-group-specific migration rates. Since age-specific migration rates for each combination of micro-regions and Census year would generate migration curves with very low rate levels (or even null rates), migration schedules were estimated for population flows among the major Brazilian regions (North, Northeast, Southeast, South and Central-West) for each Census year (1991 and 2000). The assumption is that the migration patterns among micro-regions follow the same trends of the major regions in which they are located.

This procedure generates a total of 50 population flows (five regions of origin, five regions of destination, and two Census years). As a method for standardising the information used to estimate the level and pattern of migration, these rates were estimated with data on the municipality of residence five years before each Census. This variable allows for the estimation of inter-major-regional migration, as well as intra-major-regional, because the information is obtained at the municipality level.

As noted by Amaral (2008), the age-specific out-migration rate (ASOMR $\left.\mathrm{A}_{\mathrm{x}, \mathrm{ij}}\right)$ by age group can be estimated using data on place of residence at a fixed time prior to the Census:

$$
A S O M R_{x, i j}=\frac{\sum\left(K_{i j}^{x}\right)}{t * \Sigma\left[\frac{\left(K_{i .}^{x}+K_{i i}^{x}\right)+\left(K_{i}^{x}\right)}{2}\right]},
$$

where $A S O M R_{x, i j}$ is the age-specific out-migration rate from region $i$ to region $j$ for age group $x$; $K_{x, i j}$ refers to migrants that lived in region $i$ at the beginning of the period and moved to region $j$ at the end of the period for age group $x ; K_{x, i}$ refers to migrants that lived in region $i$ at the beginning of the period and live in another region at the end of the period for age group $x$; $K_{x, i i}$ is the population that lived in region $i$ at the beginning, as well as at the end of the period for age 
group $x ; K_{x, i}+K_{x, i i}$ is the total population at the beginning of the period for age group $x ; K_{x, i}$ is all the population that lived in region $i$ at the end of the period (this is the total population at the end of the period) for age group $x ;\left[\left(K_{x, i .}+K_{x, i i}\right)+\left(K_{x, i}\right)\right] / 2$ is the estimated population at the middle of the period for age group $x$; and $t$ is the number of years between the date of reference of the Census and the fixed prior time noted as part of the migration question (1991 and 2000 Brazilian Censuses asked where people lived exactly five years before the Census, $t=5$ ). An assumption is made to calculate migration rates using this procedure. The rate of migration is the same between those who died during the five years before the Census and those who survived during this same period.

The approach in this study requires the estimation of in-migration, rather than outmigration as a method for obtaining the impact of population flows on earnings at the end of the period. Thus, the age-specific in-migration rate $\left(A S I M R_{x, i j}\right)$ by age group was estimated among the five major Brazilian regions in two Censuses $(5 * 5 * 2=50$ flows). The denominator of the equation is adjusted to estimate the population at the middle of the period for the region of destination:

$\operatorname{ASIMR}_{x, i j}=\frac{\Sigma\left(K_{i j}^{x}\right)}{t * \Sigma\left[\frac{\left(K_{j .}^{x}+K_{j j}^{x}\right)+\left(K_{j}^{x}\right)}{2}\right]}$.

Because the intention is to estimate the pattern of migration by age group, the proportional $A S I M R_{x, i j}$ was generated. The sum of all these rates by age-groups is equal to one unit, considering one region of origin, one region of destination, and one Census year. The $A S I M R_{x, i j}$ were estimated for a total of 10 age groups $(15-19,20-24,25-29,30-34,35-39,40-44,45-49$, 50-54, 55-59, and 60-64). 


\subsection{Modelling the exogenous age pattern of migration}

After the estimation of migration rates by age group, the mathematical models proposed by Rogers and Castro (1981) were implemented on the results. The regularities found in the migration schedules by age, helped develop hypothetical migration models that can be used in population studies with limited or inadequate data. In our case, since 50 migration flows among five major Brazilian regions were estimated, the observed rates can be highly influenced by outlier information. Thus, mathematical models smooth the migration rates, and assist in understanding the pattern of population flows among the areas.

The migration schedule (Rogers and Castro 1981) is composed of four components related to the labour market: (1) the pre-labour curve is a negative exponential curve from zero to 19 years-of-age ( $\alpha_{1}$ as the descendent indicator); (2) the curve for migrants of labour-age has a parabolic shape ( $\mu_{2}$ as the mean age indicator; $\lambda_{2}$ as the ascendant indicator; and $\alpha_{2}$ as the descendent indicator); (3) the post-labour curve is a small parabola signifying the individuals around 65 years-of-age ( $\mu_{3}$ as the mean age indicator; $\lambda_{3}$ as the ascendant indicator; and $\alpha_{3}$ as the descendent indicator); and (4) the last parameter of the model schedule is a constant (c) that adjusts the migration rates to the mathematic expression. This proposition establishes that migration is highly influenced by economics because the curves designate different moments of an individual's entrance into the labour market.

There are three different "multiexponential functions" used to model migration schedules (Rogers and Castro 1981). The "basic model migration schedule" has all four labour-migration components listed above. The "reduced form" does not present the post-labour curve for individuals around 65 years-of-age. The "model migration schedule with an upward slope" has a linear curve for post-labour ages, instead of a parabola. Migration flows are usually modelled 
utilizing the "reduced model," because there is no evident parabola or linear function for postlabour ages (Raymer and Rogers 2007; Rogers and Jordan 2004).

Since the purpose of the present study is to correct the income estimates of 15 to 64 yearold men, the modelling of migration rates was based on the second component (the parabola for labour-age migrants) and the fourth component (constant to adjust the mathematical expression). In other words, we used the "reduced model" without the first component (pre-labour curve) because this curve refers to the population of individuals with less than 15 years-of-age:

$S_{x}=a_{2} * \exp \left\{-\alpha_{2}\left(x-\mu_{2}\right)-\exp \left[-\lambda_{2}\left(x-\mu_{2}\right)\right]\right\}+c$.

The proportional age-specific in-migration rates $\left(A S I M R_{x, i j}\right)$ were estimated with Equation (5) and modelled with Equation (6), for the 50 population flows among the five major Brazilian regions. As an example, Figure 1 illustrates the migration flows to the Southeast region. The vertical axes are not uniform to allow for a better visualisation of the observed and modelled migration schedules for each population flow.

\section{>> Figure $1<<<$}

\subsection{Integrating the exogenous level and age pattern of migration}

After the procedures detailed above, we calculated the ratio of the level of migration for 20 to 24 year-old men (for each one of the pairs of micro-regions of origin and destination) to the age-specific in-migration rates of this same age group (ASIMR20-24,ij). This ratio took into account the migration pattern by major regions of origin and destination corresponding to the migration level by micro-regions of origin and destination. The ratio was then multiplied by each $A S I M R_{x, i j}$ of the other age groups, considering the education group and year. In other words, the migration level between the micro-regions (502 micro-regions of origin * 501 micro-regions of 
destination * 3 education groups $* 2$ Census years) was applied to the migration patterns of the major Brazilian regions ( 5 major regions of origin * 5 major regions of destination $* 2$ Census years).

Following this procedure, the total non-in-migration rate $\left(T N I M R_{i j}\right)$ was estimated for each one of the 12 age-education groups related to the earning models, for each Census and each combination of micro-region of origin and destination. This rate is estimated using the $A S I M R_{x, i j}$ (Amaral 2008):

$T N I M R_{g, i j}=\exp \left(-\sum A S I M R_{x, e, i j}\right)$

where $g$ represents the combination of age (15-24, 25-34, 35-49, and 50-64) and education (0$4,5-8$, and 9+) groups, and there are 12 combinations; $x$ is the five-year age group; and $e$ is the education group.

The total in-migration rate $\left(T I M R_{i j}\right)$ was calculated using the $T N I M R_{i j}$ :

$T I M R_{i j}=1-T N I M R_{i j}$

\subsection{Force of migration}

Finally, a measure of the force of migration was estimated as the sum of all total inmigration rates for each micro-region of destination. In other words, all TIMR $i j$ from microregions of origin to a specific micro-region of destination were added, considering each ageeducation group and year. This procedure generated a total of 12,048 estimates of the force of migration (502 micro-regions $* 12$ age-education groups $* 2$ Census years). These estimated migration rates were merged with the data on the earnings of workers.

The new measurements of the rate of migration by age-education groups allow for the estimation of exogenous impacts of migration on the income of workers, removing the 
endogeneity of the original migration variables. These exogenous measures of population flows were introduced in Equations 1 and 2, as migration rates categorized by age-education groups $(M g)$. 


\section{Results}

Table 2 illustrates the national migration rates by age-education groups in Brazil, between 1970 and 2000. These rates were obtained by averaging the micro-region rates, as well as by taking into account the number of age-education cells of each micro-region. Males were first defined as migrants if they were born in another state. Because this is a variable that measures the stock of migrants in one area, older groups present higher rates. Moreover, within the same age group, migration rates are higher for those with more education. Furthermore, there is a decline in the rates of these migrants in more recent years. In the second set of migratory rates, males were defined as migrants if they lived for less than five years in the municipality of residence. This variable reports the recent flow of migrants into one area and, therefore, has a lower value than variables determined using the state of birth. In general, there is a greater inflow of recent migrants for all ages into the group with the least amount of education. However, between 1970 and 2000, the migration rates decreased for the least educated group, and increased for the other groups. This might be an indication that previous flows of poorlyeducated males (mainly rural-urban migration) are now being replaced by population flows of better-educated migrants.

\section{>> Table $2<<<$}

\subsection{Endogenous influence of migration on earnings}

Table 3 shows results for the regression model that estimate the impacts of age-education indicators and migration rates on the logarithm of mean real monthly earnings from primary occupation, based on Equation (1). For this model, migrants are those born in a state different from their state of residence. The age-education-group indicators demonstrate that earnings 
increase with age and years of schooling. The coefficients of migration rates show a significantly positive impact on earnings in 1970 for almost all age-education groups. This positive impact is even stronger in 1991, but is not statistically significant for the 50-64 age group. In 2000, the negative impacts occurring in the group with 5-8 years of education for those with 15-24 and 25-39 years-of-age counterbalance the positive impacts of 1970. This intermediary educational group has an even stronger positive impact in 2000 for the 50-64 age group.

\section{>> Table $3<<<$}

Table 4 estimates Equation (1) using information on less than five years in the municipality of residence to define migrants. The age-education-group indicators have the same patterns as those of Table 3 . However, the migration coefficients illustrate a negative impact on earnings in 1970. These impacts are statistically significant for the intermediary age-education groups in 1970. The other significant coefficients are related to the 25-34 and 35-49 age groups and indicate: (1) higher negative impacts on earnings in recent years for the least-educated group, as well as (2) lower negative impacts in recent years for the most-educated group.

\section{>> Table $4<<<$}

Since the migration coefficients in Tables 3 and 4 refer to different migration rates, it is necessary to standardize these measures in order to better demonstrate and compare the impact of migration rates on earnings. Thus we calculated elasticities $\{$ [exponential(coefficient*migration rate*0.01)-1]*100\}, which provide the ratio of the percentage change in our dependent variable (logarithm of earnings) due to a percentage change in our independent variables (migration rates). We used the national migration rates by age-education group and year (Table 2) and the estimated migration coefficients (Tables 3 and 4), as a way to verify the magnitude of our coefficients. 
In the first set of estimations of Table 5 (first four columns), state of birth was used to categorize individuals as migrants or naturals in each micro-region. The elasticities are greater for the model with this migration variable for the least educated group. As suggested by Table 3, these impacts are diminishing over time, but they are even more positive for individuals between 50 and 64 years-of-age with more education (five to eight years of schooling, and at least nine years of schooling). The elasticities of these models are not in line with Borjas' findings (2003), in which migration rates have a negative impact on earnings. This difference might be caused by the fact that the state of birth takes into account migration movements over a long period of time.

\section{>> Table $5<<<$}

The second set of estimations in Table 5 (last four columns) took into account the classification of migrants as those that lived for less than five years in the municipality. This model shows the negative impact of migration on earnings since 1970. This negative impact is even stronger in 2000 for most age-education groups: 15-24 years (all education groups); 25-34 (0-4 and 5-8 years of schooling); and 35-49 (0-4 and 5-8 years of schooling). These elasticities are not significant for the oldest age groups, which might be related to the groups' low migration rates (Table 2). In 2000, the strongest elasticities are observed for the following age-education groups: 15-24 (5-8 and 9+ years of schooling); 25-34 (5-8 years of schooling); and 35-49 (0-4 and 5-8 years of schooling). For instance, a 10 percent increase in the migration rate of the ageeducation group with 15-24 years-of-age and 5-8 years of schooling, reduces their earnings by 1.41 percent $(-0.141)$ in 2000 . The negative impacts of migration on earnings are not consistent across all age-education groups, which might be an indication that more precise migration variables should be used in the models. 


\subsection{Exogenous influence of migration on earnings}

In order to verify whether the exogenous migration rates generate more suitable results than the ones provided by observed migration variables, a set of models is compared in this section. Before introducing this exogenous migration variable to the models, it was important to verify whether models using only the 1991 and 2000 Censuses generate elasticities similar to those estimated by all Censuses. Two models based on Table 3 (born in a different state) and Table 4 (less than five years in the municipality of residence) were re-estimated using only the 1991 and 2000 Censuses. Two other models were also generated, using: (1) information on residence five years before the Census; and (2) the exogenous measure of migration. The elasticities for these four models are presented in Table 6, and were generated in the same way as those noted in Table 5. These elasticities took into account coefficients from the new 1991-2000 regression models (not shown). Note that the national migration rates by age-education groups are only illustrated for information on born in a different state and less than five years in the municipality of residence (Table 2), but not for data on residence five years before the Census and the adjusted-migration (exogenous) estimates. This descriptive information is not reported at this point. The new effects of in-migration rates on earnings are the most significant trends to analyse (Table 6).

\section{>> Table $6<<<$}

In relation to estimates using state of birth, the elasticities from the 1991-2000 model (first two columns of Table 6) have the same magnitude and composition as the 1970-2000 model (third and fourth columns of Table 5). The model with information on less than five years in the municipality of residence also generated similar elasticities, when the newer model was developed (third and fourth columns of Table 6), compared to previous estimates (last two 
columns of Table 5). Based on these findings, we can compare the elasticities among the four different models in Table 6, knowing that the exclusion of the 1970 and 1980 Censuses from this analysis does not bias the new coefficients.

Another model in Table 6 used information on municipality of residence five years before the Censuses (fifth and sixth columns of Table 6). As expected, the elasticities of this model have a magnitude similar to the ones generated using time of residence. This result is explained by the fact that information on time of residence deals with the same type of migration movement as was included in information on municipality of residence five years before the Census.

The adjusted-migration estimates were generated with data on municipality of residence five years before the Census, which were corrected utilizing level (Stillwell 2009) and age pattern (Rogers and Castro 1981) techniques (last two columns of Table 6). As occurred before, migration rates present a negative impact on earnings, but this impact is not consistent throughout the years and across all age-education groups. For instance, a 10 percent increase in the exogenous migration rate would reduce earnings of competing male workers by up to 0.6 percent in 2000 (25-34 years; 9+ years of schooling). On the other hand, a 10 percent increase of this migration rate would increase earnings of workers by 1.42 percent $(0.142)$, among those with 50-64 years-of-age and 9+ years of schooling in 2000.

As a strategy for controlling our estimates using changes of the age and educational compositions of each micro-region over time, Equation (2) was estimated for each one of the four migration variables. The elasticities provided by these models were calculated in the same way as in Tables 5 and 6, and are illustrated in Table 7. The model that includes state of birth, still expresses the positive impact of migration on earnings. The models with information on less 
than five years in the municipality of residence and municipality of residence five years prior to the Census have elasticities that are even more positive than the ones presented in Table 6 .

\section{>> Table $7<<<$}

The model generated by Equation (2) with the exogenous measure of migration, has elasticities consistent with the initial hypothesis: in-migration flows have a negative impact on male earnings. Only four age-education groups present positive elasticities: $25-34$ years-of-age with 9+ years of schooling (1991); 35-49 years-of-age with 5-8 and 9+ years of schooling (1991); and 50-64 years-of-age with 9+ years of schooling (2000). Among the negative elasticities in 1991, a 10 percent increase in the migration rate would decrease earnings of workers from 0.12 percent (-0.012) (50-64 years-of-age and 9+ years of schooling) to 3.41 percent $(-0.341)$ (50-64 years-of-age and 5-8 years of schooling). In 2000, the negative range goes from 0.12 percent $(-0.012)$ (15-24 years-of-age and 9+ years of schooling) to almost three percent ( -0.257$)$ (35-49 years-of-age and 5-8 years of schooling). From 1991 to 2000, the elasticities increased their negative values for the least-educated group ( $0-4$ years of schooling). For the other groups, there are different trends between the years. Our final results are consistent with previous studies, which estimate the negative impact of migration flows on the earnings of competing workers (Borjas 2003). 


\section{Final considerations}

This paper dealt with the important relationship between internal migration and earnings.

Our study was concerned with the reverse causality that exists between migration flows and the level of earnings (Muth 1971). On one hand, migrants usually move towards areas that have higher job opportunities and income levels, when compared to the areas of origin. On the other

hand, a greater proportion (supply) of migrants can affect the levels of earnings in one area. This analysis deals with regional equilibrium models that have been addressing the relationship of migration and earnings (Greenwood et al. 1991; Lee 1966; Passaris 1989; Ravenstein 1885, 1889).

We developed a methodology that estimates exogenous measures of migration, in order to be included in models that analyse the impact of population flows on earnings. Our methodological procedures were applied in order to understand how internal migration flows in Brazil impacted the earnings of male workers between 1970 and 2000. The findings of this study follow the initial hypothesis, which stated that migration streams negatively impact earnings. A 10 percent increase in migration rates would have reduced earnings of competing workers by up to three percent in 2000 . This negative impact is consistent with studies related to U.S. immigration (Borjas 2003).

Since migration flows both explain and are defined by the level of earnings in one area, the inclusion of internal migration in the models generated consistent results when this simultaneity issue was controlled. Our negative elasticities are consistent throughout age-education groups only when controlling for cohort size. Thus, our models also consider that composition of the workforce in terms of age and education has an influence on earnings (large cohorts depress earnings). 
Although we estimated the adjusted-migration rates only for 1991 and 2000 in Brazil, these methodological strategies can be used in further studies with the availability of new data and in the context of other countries. The study of the associations between migration flows and labour outcomes is important for countries that experience considerable internal migration and immigration flows.

Future studies could investigate the long-term effects of in-migration, which increases labour supply and competition in the labour markets, as well as raises demand for services and stimulates economic growth in receiving areas. These analyses could also examine the economic adjustments experienced by labour markets with high levels of in-migration flows. Population streams affect economic opportunities, at the same time that businesses and workers adapt and take advantage of new labour configurations. Public policies should take into account that shortterm negative effects of migration flows on earnings (as the ones estimated in this paper) might be overcome by investments for economic growth that would absorb the increasing working-age population.

Opposite economic responses could happen in areas with high out-migration rates, which bring up important topics to conduct further investigations in different countries. This issue can be evaluated in terms of the connections between migration flows and fertility levels. For instance, Brazil experienced a drop in total fertility rates from 6.28 children per women in 1960 to 1.90 in 2010, according to the Brazilian Census Bureau. This decline is happening even in rural areas and small municipalities. Thus migration flows from small to middle or big municipalities, conjugated with fertility decline, might generate empty areas in different countries, which would have negative socioeconomic consequences. If migration flows adjust to the decline in fertility, spatial distribution would move towards a faster stabilization process. 
Spatial analyses could be performed to evaluate these associations between migration, fertility, and labour outcomes. Public policies would have to deal with issues of declining population in certain locations and stimulate economic development in different areas, instead of concentrating the production in specific regions.

\section{References}

Amaral, E.F.L., J.E. Potter, D.S. Hamermesh, E.L.G. Rios-Neto. 2013. Age, education and earnings in the course of Brazilian development: does composition matter?, Demographic Research 28(20): 581-612.

Amaral, E.F.L. 2008. Improvements of techniques to estimate migration rates: an application with Brazilian censuses data, Population Review 47(2): 1-24.

Amaral, E.F.L. 2013. Brazil, internal migration, in I. Ness (ed.), The Encyclopedia of Global Human Migration. Oxford: Wiley-Blackwell, pp. 1-7.

Baeninger, R. 2000. São Paulo no contexto dos movimentos migratórios interestaduais [São Paulo in the context of inter-state migratory movements], in D.J. Hogan, J.M.P. Cunha, R. Baeninger, and R.L. Carmo (eds.), Migração e Ambiente em São Paulo: Aspectos Relevantes da Dinâmica Recente [Migration and Environment in São Paulo: Relevant Aspects of the Recent Dynamic]. Campinas: Population Studies Center (NEPO), University of Campinas (UNICAMP), pp. 127-169.

Berger, M. 1985. The effect of cohort size on earnings growth: a reexamination of the evidence, The Journal of Political Economy 93(3): 561-573.

Berker, A. 2011. Labor-market consequences of internal migration in Turkey, Economic Development and Cultural Change 60(1): 197-239. 
Biagi, F. and C. Lucifora. 2008. Demographic and education effects on unemployment in Europe, Labour Economics 15: 1076-1101.

Borjas, G.J. 2003. The labor demand curve is downward sloping: reexamining the impact of immigration on the labor market, The Quarterly Journal of Economics November: 13351374.

Boustan, L.P., P.V. Fishback, and S. Kantor. 2010. The effect of internal migration on local labor markets: American cities during the Great Depression, Journal of Labor Economics 28(4): 719-746.

Braga, F.G. and D.F.A. Rezende. 2010. Análise de redes sociais e as conexões territoriais da migração no Brasil: padrões estruturais da migração interna entre 1980 e 2000 [Analysis of social networks and the territorial connections of migration in Brazil: structural patterns of internal migration between 1980 and 2000], XVII Encontro Nacional de Estudos Populacionais [Seventeenth Brazilian National Meeting of Population Studies], Caxambu 2010. Caxambu: Brazilian Association of Population Studies (ABEP).

Brito, F. and J.A.M. Carvalho. 2006. As migrações internas no Brasil: as novidades sugeridas pelos censos demográficos de 1991 e 2000 e pelas PNADs recentes [Internal migration in Brazil: news suggested by 1991-2000 demographic censuses and by recent national household surveys], XV Encontro Nacional de Estudos Populacionais [Fifteenth Brazilian National Meeting of Population Studies], Caxambu 2006. Caxambu: Brazilian Association of Population Studies (ABEP).

Brito, F., C.J.G. Horta, and E.F.L. Amaral. 2001. The Brazilian recent urbanization and the urban conurbations, International Population Conference, Salvador 2001. Salvador: International Union for the Scientific Study of Population (IUSSP). 
Brunello, G. 2010. The effects of cohort size on European earnings, Journal of Population Economics 23: 273-290.

Cattaneo, C., C.V. Fiorio, and G. Peri. 2013. Immigration and careers of European workers: Effects and the role of policies. IZA Journal of European Labor Studies, 2(17): 1-26.

Corseuil, C.H. and M.N. Foguel. 2002. Uma sugestão de deflatores para rendas obtidas a partir de algumas pesquisas domiciliares do IBGE [A suggestion of deflators for earnings obtained from some IBGE household surveys], Brazilian Institute of Applied Economic Research (IPEA) Working Paper 897.

Cunha, J.M.P. (ed.). 2006. Novas Metrópoles Paulistas: População, Vulnerabilidade e Segregação [New Metropolis in São Paulo: Population, Vulnerability and Segregation]. Campinas: Population Studies Center (NEPO), University of Campinas (UNICAMP). Cunha, J.M.P. and R. Baeninger. 2000. A migração nos estados brasileiros no período recente: principais tendências e mudanças [Migration in Brazilian states in the recent period: main tendencies and changes], in D.J. Hogan, J.M.P. Cunha, R. Baeninger, and R.L. Carmo (eds.), Migração e Ambiente em São Paulo: Aspectos Relevantes da Dinâmica Recente [Migration and Environment in São Paulo: Relevant Aspects of the Recent Dynamic]. Campinas: Population Studies Center (NEPO), University of Campinas (UNICAMP), pp. 17-57. de Haas, H. 2007. The Myth of Invasion: Irregular migration from West Africa to the Maghreb and the European Union. Oxford: International Migration Institute, University of Oxford. de Hass H. 2009. Migration transitions a theoretical and empirical inquiry into the developmental drivers of international migration, International Population Conference, Marrakech 2009. Marrakech: International Union for the Scientific Study of Population (IUSSP). 
Easterlin, R.A. 1978. What will 1984 be like? Socioeconomic implications of recent twists in age structure, Demography 15(4): 397-432.

Foged, M. and G. Peri. 2015. Immigrants' effect on native workers: New analysis on longitudinal data. IZA Discussion Paper Series, 8961: 1-47.

Freeman, R.B. 1979. The effect of demographic factors on age-earnings profiles, The Journal of Human Resources 14(3): 289-318.

Golgher, A.B. and D.H.F. Marques. 2009. Diversidad socioeconómica regional de los flujos de migración interna en Brasil [Regional socioeconomic diversity of internal migration flows in Brazil], Economía, Sociedad y Território 9(31): 681-721.

Golgher, A.B. 2008. As cidades e a classe criativa no Brasil: diferenças espaciais na distribuição de indivíduos qualificados nos municípios brasileiros [Cities and the creative class in Brazil: spatial differences in the distribution of qualified individuals in Brazilian municipalities], Revista Brasileira de Estudos de População 25(1): 109-129.

Greenwood, M.J., G.L. Hunt, D.S. Rickman, and G.I. Treyz. 1991. Migration, regional equilibrium, and the estimation of compensating differentials, The American Economic Review 81(5): 1382-1390.

Head, K. 2000. Gravity for beginners. Rethinking the Line: the Canada-U.S. Border Conference, Vancouver 2000. Vancouver: Government of Canada.

Katz, L.F. and D.H. Autor. 1999. Changes in the wage structure and earnings inequality, in O. Ashenfelter and D. Card (eds.), Handbook of Labor Economics, Volume 3, Part 1. Amsterdam: North-Holland, pp. 1463-1555.

Katz, L.F. and K.M. Murphy. 1992. Changes in relative wages, 1963-1987: supply and demand factors, The Quarterly Journal of Economics 107(1): 35-78. 
Korenman, S. and D. Neumark. 2000. Cohort crowding and youth labor markets: a crosssectional analysis, in D. Blanchflower and R. Freeman (eds.), Youth Employment and Joblessness in Advanced Countries. Chicago: NBER Chicago University Press, pp. 57-105.

Korpi, M. 2008. Does size of local labour markets affect wage inequality? A rank-size rule of income distribution, Journal of Economic Geography 8(2): 211-237.

Lee, E.S. 1966. A theory of migration. Demography 3: 47-57.

Lima, E.E.C. and F.G. Braga. 2010. Da rotatividade migratória à baixa migração: uma tipologia dos padrões da mobilidade populacional no Brasil [From migratory turnover to low migration: one typology of population mobility patterns in Brazil], XVII Encontro Nacional de Estudos Populacionais [Seventeenth Brazilian National Meeting of Population Studies], Caxambu 2010. Caxambu: Brazilian Association of Population Studies (ABEP).

Lowry, I.S. 1966. Migration and Metropolitan Growth: Two Analytical Models. San Francisco: Chandler Publishing.

Mansour, H. 2010. The effects of labor supply shocks on labor market outcomes: evidence from the Israeli-Palestinian conflict, Labour Economics 17(6): 930-939.

Matos, R.E.S. (ed.). 2005a. Espacialidades em Rede: População, Urbanização e Migração no Brasil Contemporâneo [Spatiality in Network: Population, Urbanization and Migration in Contemporary Brazil]. Belo Horizonte: Editora Com Arte.

Matos, R.E.S. 2005b. Periferias de grandes cidades e movimentos populacionais [Peripheries in big cities and population movements], Cadernos Metrópole 13: 71-105.

Matos, R.E.S. and W. Soares (eds.). 2009. Desigualdades, Redes e Espacialidades Emergentes no Brasil [Inequalities, Networks and Emerging Spatiality in Brazil]. Rio de Janeiro: Garamond. 
McDowell, C. and A. de Haan. 1997. Migration and sustainable livelihoods: a critical review of the literature, Institute of Development Studies (IDS) Working Paper 65.

Moretti, E. 2004. Estimating the social return to higher education: evidence from longitudinal and repeated cross-sectional data, Journal of Econometrics 121: 175-212.

Muth, R.F. 1971. Migration: chicken or egg?, Southern Economic Journal 37(3): 295-306.

Oliveira, K.F. and P.M. Jannuzzi. 2005. Motivos para migração no Brasil e retorno ao Nordeste, São Paulo em Perspectiva 19: 134-143.

Passaris, C. 1989. Immigration and the Evolution of Economic Theory, International Migration 27: 525-542.

Peri, G. 2014. Do immigrant workers depress the wages of native workers? IZA World of Labor, 42: 1-10.

Piedad Urdinola, B. and B.L. Queiroz. 2013. Latin American Human Mortality Database. Available at www.lamortalidad.org (data downloaded on May 17, 2013).

Potter, J.E., C.P. Schmertmann, and S.M. Cavenaghi. 2002. Fertility and development: evidence from Brazil, Demography 39: 739-761.

Poyhonen, P. 1963. A tentative model for volume in trade between countries, Weltwirtschaftliches Archive 90: 91-113.

Ravenstein, E.G. 1885. The laws of migration, Journal of the Royal Statistical Society 48: 167227.

Ravenstein, E.G. 1889. The laws of migration, Journal of the Royal Statistical Society 52: 214301.

Raymer, J. and A. Rogers. 2007. Using age and spatial flow structures in the indirect estimation of migration streams, Demography 44(2): 199-223. 
Rigotti, J.I.R. 2006. Geografia dos fluxos populacionais segundo níveis de escolaridade dos migrantes [Geography of population flows by levels of schooling of migrants], Estudos Avançados 20(57): 237-254.

Rogers, A. and L.J. Castro. 1981. Model Migration Schedules. Laxenburg: International Institute for Applied Systems Analysis.

Rogers, A. and L. Jordan. 2004. Estimating migration flows from birthplace-specific population stocks of infants, Geographical Analysis 36(1): 38-53.

Sapozknikov, M. and R.K. Triest. 2007. Population aging, labor demand, and the structure of wages, Work Opportunities for Older Americans Series Working Paper 8.

Shimer, R. 2001. The impact of young workers on the aggregate labor market, The Quarterly Journal of Economics 116(3): 969-1007.

Skans, O.N. 2005. Age effects in Swedish local labor markets, Economics Letters 86: 419-426.

Stillwell, J. 2009. Inter-regional migration modelling: a review, in J. Poot, B. Waldorf, and L. van Wissen (eds.), Migration and Human Capital. Cheltenham: Edward Elgar, pp. 29-48.

Tinbergen, J. 1962. Shaping the World Economy. New York: Twentieth Century Fund.

Welch, F. 1979. Effects of cohort size on earnings: the baby boom babies' financial bust, The Journal of Political Economy 87(5)2: S65-S97. 
Figure 1. Observed and estimated proportional age-specific in-migration rates (ASIMR) of flows to the Southeast region, 1991 and 2000. ${ }^{1}$

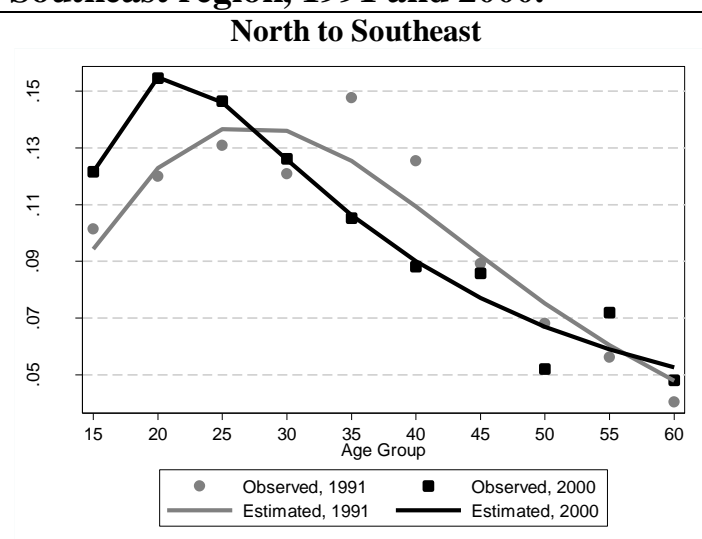

Southeast to Southeast

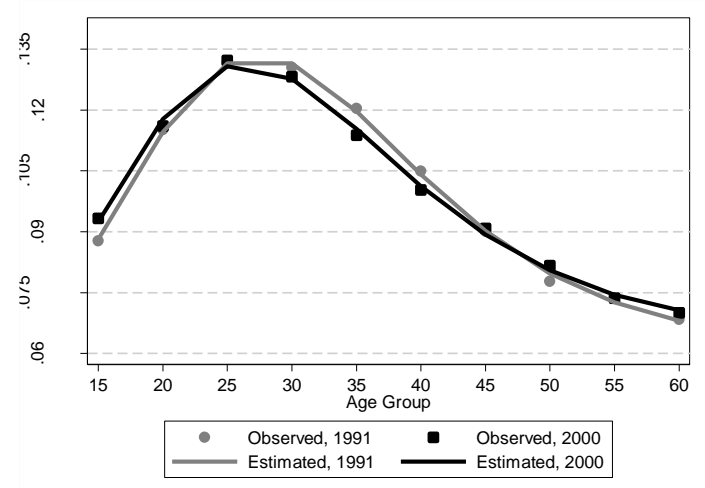

Central-West to Southeast

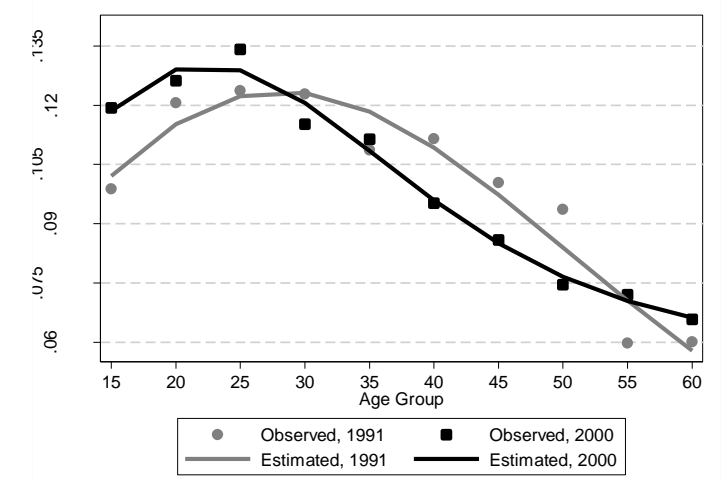

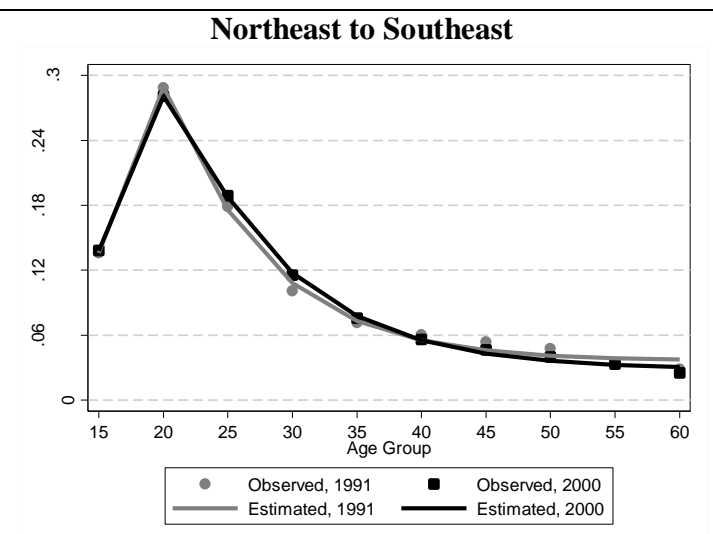

South to Southeast

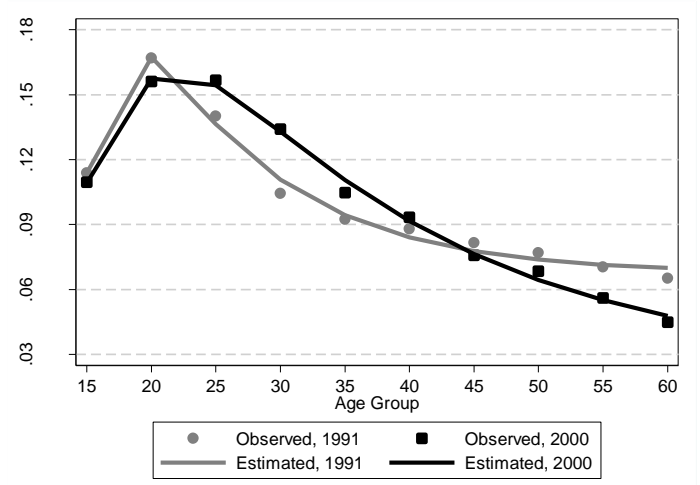

${ }^{1}$ Migration flows were estimated with information on municipality of residence five years before each Census reference date. This allows for the estimation of intra-regional migration in each period. The vertical axes are not uniform to allow a better visualisation of the observed and modelled migration schedules for each population flow.

Sources: 1991 and 2000 Brazilian Demographic Censuses. 
Table 1. Poisson estimates of population at the beginning and end of the period, and distance between micro-region centroids on the logarithm of migration flows for men aged 20-24 years (dependent variable) by education group, Brazil, 1991 and 2000.

\begin{tabular}{|c|c|c|c|c|c|c|}
\hline Variables & $\begin{array}{c}\text { 0-4 years } \\
\text { of schooling }\end{array}$ & $\begin{array}{c}1991 \\
5-8 \text { years } \\
\text { of schooling }\end{array}$ & $\begin{array}{c}9+\text { years } \\
\text { of schooling }\end{array}$ & $\begin{array}{c}\text { 0-4 years } \\
\text { of schooling }\end{array}$ & $\begin{array}{c}2000 \\
5-8 \text { years } \\
\text { of schooling }\end{array}$ & $\begin{array}{c}9+\text { years } \\
\text { of schooling }\end{array}$ \\
\hline Constant & $\begin{array}{c}-6.848 * * * \\
(0.0692)\end{array}$ & $\begin{array}{c}-5.541 * * * \\
(0.0642)\end{array}$ & $\begin{array}{c}-5.325 * * * \\
(0.0692)\end{array}$ & $\begin{array}{c}-7.696 * * * \\
(0.0823)\end{array}$ & $\begin{array}{c}-6.947 * * * \\
(0.0677)\end{array}$ & $\begin{array}{c}-6.400 * * * \\
(0.0667)\end{array}$ \\
\hline $\begin{array}{l}\text { Log of population } \\
\text { aged } 15-19 \text { years } \\
\text { at the beginning } \\
\text { of the period in } \\
\text { micro-region } i\end{array}$ & $\begin{array}{l}0.648 * * * \\
(0.00507)\end{array}$ & $\begin{array}{l}0.525 * * * \\
(0.00434)\end{array}$ & $\begin{array}{l}0.557 * * * \\
(0.00468)\end{array}$ & $\begin{array}{l}0.710^{* * * *} \\
(0.00615)\end{array}$ & $\begin{array}{l}0.593 * * * \\
(0.00457)\end{array}$ & $\begin{array}{l}0.534 * * * \\
(0.00408)\end{array}$ \\
\hline $\begin{array}{l}\text { Log of population } \\
\text { aged } 20-24 \text { years } \\
\text { at the end } \\
\text { of the period in } \\
\text { micro-region } j\end{array}$ & $\begin{array}{l}0.831^{* * * *} \\
(0.00513)\end{array}$ & $\begin{array}{l}0.719 * * * \\
(0.00399)\end{array}$ & $\begin{array}{l}0.688^{* * * *} \\
(0.00409)\end{array}$ & $\begin{array}{l}0.780^{* * * *} \\
(0.00590)\end{array}$ & $\begin{array}{l}0.753 * * * \\
(0.00417)\end{array}$ & $\begin{array}{l}0.698 * * * \\
(0.00376)\end{array}$ \\
\hline $\begin{array}{c}\text { Log of KM } \\
\text { distances between } \\
\text { micro-regions }\end{array}$ & $\begin{array}{l}-1.093 * * * \\
(0.00503)\end{array}$ & $\begin{array}{l}-0.965 * * * \\
(0.00568)\end{array}$ & $\begin{array}{l}-0.963 * * * \\
(0.00661)\end{array}$ & $\begin{array}{c}-1.063 * * * \\
(0.00560)\end{array}$ & $\begin{array}{l}-0.973 * * * \\
(0.00547)\end{array}$ & $\begin{array}{l}-0.933 * * * \\
(0.00574)\end{array}$ \\
\hline Observations (n) & 251,502 & 251,502 & 251,502 & 251,502 & 251,502 & 251,502 \\
\hline
\end{tabular}

${ }^{*}$ Significant at $\mathrm{p}<0.1 ;{ }^{* *}$ Significant at $\mathrm{p}<0.05 ;{ }^{* * *}$ Significant at $\mathrm{p}<0.01$.

Standard errors in parentheses.

Sources: 1991 and 2000 Brazilian Demographic Censuses. 
Table 2. Migration rates of the male working-age population by age-education group, Brazil, 19702000.

\begin{tabular}{|c|c|c|c|c|c|c|c|c|}
\hline \multirow{2}{*}{$\begin{array}{c}\text { Age-education } \\
\text { groups }\end{array}$} & \multicolumn{4}{|c|}{ Born in a different state } & \multicolumn{4}{|c|}{ Less than five years in the municipality of residence } \\
\hline & 1970 & 1980 & 1991 & 2000 & 1970 & 1980 & 1991 & 2000 \\
\hline $\begin{array}{c}15-24 \text { years } \\
0-4 \text { years of schooling }\end{array}$ & 0.199 & 0.208 & 0.185 & 0.179 & 0.335 & 0.248 & 0.175 & 0.100 \\
\hline $\begin{array}{c}15-24 \text { years } \\
5-8 \text { years of schooling }\end{array}$ & 0.178 & 0.151 & 0.144 & 0.133 & 0.053 & 0.104 & 0.139 & 0.142 \\
\hline $\begin{array}{c}15-24 \text { years } \\
9+\text { years of schooling }\end{array}$ & 0.193 & 0.136 & 0.129 & 0.111 & 0.032 & 0.059 & 0.069 & 0.111 \\
\hline $\begin{array}{c}25-34 \text { years } \\
0-4 \text { years of schooling }\end{array}$ & 0.250 & 0.262 & 0.240 & 0.250 & 0.228 & 0.190 & 0.148 & 0.101 \\
\hline $\begin{array}{c}25-34 \text { years } \\
5-8 \text { years of schooling }\end{array}$ & 0.255 & 0.233 & 0.200 & 0.207 & 0.023 & 0.043 & 0.078 & 0.089 \\
\hline $\begin{array}{c}25-34 \text { years } \\
9+\text { years of schooling }\end{array}$ & 0.259 & 0.217 & 0.173 & 0.168 & 0.026 & 0.060 & 0.095 & 0.108 \\
\hline $\begin{array}{c}35-49 \text { years } \\
0-4 \text { years of schooling }\end{array}$ & 0.266 & 0.276 & 0.266 & 0.270 & 0.188 & 0.149 & 0.138 & 0.110 \\
\hline $\begin{array}{l}35-49 \text { years } \\
5-8 \text { years of schooling }\end{array}$ & 0.299 & 0.261 & 0.239 & 0.233 & 0.012 & 0.017 & 0.028 & 0.056 \\
\hline $\begin{array}{c}35-49 \text { years } \\
9+\text { years of schooling }\end{array}$ & 0.316 & 0.263 & 0.226 & 0.204 & 0.013 & 0.023 & 0.048 & 0.080 \\
\hline $\begin{array}{c}50-64 \text { years } \\
0-4 \text { years of schooling }\end{array}$ & 0.283 & 0.279 & 0.273 & 0.288 & 0.082 & 0.067 & 0.066 & 0.062 \\
\hline $\begin{array}{c}50-64 \text { years } \\
5-8 \text { years of schooling }\end{array}$ & 0.356 & 0.299 & 0.264 & 0.267 & 0.003 & 0.004 & 0.006 & 0.012 \\
\hline $\begin{array}{c}50-64 \text { years } \\
9+\text { years of schooling }\end{array}$ & 0.372 & 0.311 & 0.268 & 0.255 & 0.003 & 0.005 & 0.009 & 0.019 \\
\hline Total & 0.268 & 0.241 & 0.217 & 0.214 & 0.084 & 0.081 & 0.083 & 0.083 \\
\hline Male population & $25,760,600$ & $32,613,947$ & $43,434,546$ & $53,177,953$ & $25,760,600$ & $32,613,947$ & $43,434,546$ & $53,177,953$ \\
\hline
\end{tabular}


Table 3. Fixed-effects estimates of age-education indicators and migration rates by age-education groups (born in a different state) on the logarithm of mean real monthly earnings from primary occupation ${ }^{1}$ (dependent variable), Brazil, 1970-2000.

\begin{tabular}{|c|c|c|c|c|}
\hline \multirow{2}{*}{$\begin{array}{l}\text { Variables } \\
\text { Constant }\end{array}$} & \multicolumn{4}{|c|}{ Coefficients and standard errors } \\
\hline & $\begin{array}{l}5.265 * * * \\
(0.00569) \\
\end{array}$ & & & \\
\hline \multirow[b]{2}{*}{ Age-education indicators } & Main effects & \multicolumn{3}{|c|}{ Interactions with year } \\
\hline & 1970 & 1980 & 1991 & 2000 \\
\hline 15-24 years; 0-4 years of schooling (reference group) & - & - & - & - \\
\hline \multirow{2}{*}{$\begin{array}{l}\text { 15-24 years; } 5-8 \text { years of schooling } \\
15-24 \text { years; } 9+\text { years of schooling }\end{array}$} & $\begin{array}{c}0.557 * * * \\
(0.0165)\end{array}$ & $\begin{array}{c}-0.270 * * * \\
(0.0216)\end{array}$ & $\begin{array}{c}-0.244 * * * \\
(0.0221)\end{array}$ & $\begin{array}{c}-0.350 * * * \\
(0.0229)\end{array}$ \\
\hline & $\begin{array}{l}1.035 * * * \\
(0.0193)\end{array}$ & $\begin{array}{c}-0.252 * * * \\
(0.0245)\end{array}$ & $\begin{array}{c}-0.256 * * * \\
(0.0248)\end{array}$ & $\begin{array}{c}-0.484 * * * \\
(0.0252)\end{array}$ \\
\hline $25-34$ years; $0-4$ years of schooling & $\begin{array}{c}0.346 * * * \\
(0.0141)\end{array}$ & $\begin{array}{c}0.0693 * * * \\
(0.0200)\end{array}$ & $\begin{array}{l}0.00325 \\
(0.0202)\end{array}$ & $\begin{array}{l}-0.0171 \\
(0.0205)\end{array}$ \\
\hline 25-34 years; 5-8 years of schooling & $\begin{array}{l}1.278 * * * \\
(0.0175)\end{array}$ & $\begin{array}{c}-0.220 * * * \\
(0.0234)\end{array}$ & $\begin{array}{c}-0.410 * * * \\
(0.0230)\end{array}$ & $\begin{array}{c}-0.476 * * * \\
(0.0234)\end{array}$ \\
\hline 25-34 years; $9+$ years of schooling & $\begin{array}{l}1.918 * * * \\
(0.0197) \\
\end{array}$ & $\begin{array}{c}-0.210 * * * \\
(0.0258)\end{array}$ & $\begin{array}{c}-0.396 * * * \\
(0.0251) \\
\end{array}$ & $\begin{array}{c}-0.548 * * * \\
(0.0254) \\
\end{array}$ \\
\hline 35-49 years; $0-4$ years of schooling & $\begin{array}{c}0.520 * * * \\
(0.0143)\end{array}$ & $\begin{array}{c}0.0976 * * * \\
(0.0202)\end{array}$ & $\begin{array}{c}0.104 * * * \\
(0.0205)\end{array}$ & $\begin{array}{c}0.0490 * * \\
(0.0208)\end{array}$ \\
\hline $35-49$ years; $5-8$ years of schooling & $\begin{array}{c}1.680 * * * \\
(0.0199)\end{array}$ & $\begin{array}{c}-0.146 * * * \\
(0.0262)\end{array}$ & $\begin{array}{c}-0.352 * * * \\
(0.0259)\end{array}$ & $\begin{array}{c}-0.538 * * * \\
(0.0255)\end{array}$ \\
\hline 35-49 years; $9+$ years of schooling & $\begin{array}{c}2.289 * * * \\
(0.0232) \\
\end{array}$ & $\begin{array}{c}-0.143 * * * \\
(0.0297)\end{array}$ & $\begin{array}{c}-0.217 * * * \\
(0.0288) \\
\end{array}$ & $\begin{array}{c}-0.367 * * * \\
(0.0285) \\
\end{array}$ \\
\hline 50-64 years; 0-4 years of schooling & $\begin{array}{c}0.521 * * * \\
(0.0145)\end{array}$ & $\begin{array}{c}0.0697 * * * \\
(0.0205)\end{array}$ & $\begin{array}{c}0.109 * * * \\
(0.0206)\end{array}$ & $\begin{array}{c}0.128 * * * \\
(0.0210)\end{array}$ \\
\hline 50-64 years; $5-8$ years of schooling & $\begin{array}{c}1.855 * * * \\
(0.0250)\end{array}$ & $\begin{array}{c}-0.108 * * * \\
(0.0333)\end{array}$ & $\begin{array}{c}-0.276 * * * \\
(0.0327)\end{array}$ & $\begin{array}{c}-0.459 * * * \\
(0.0306)\end{array}$ \\
\hline 50-64 years; $9+$ years of schooling & $\begin{array}{c}2.408 * * * \\
(0.0322)\end{array}$ & $\begin{array}{c}-0.151 * * * \\
(0.0412)\end{array}$ & $\begin{array}{c}-0.0782 * * \\
(0.0398)\end{array}$ & $\begin{array}{c}-0.173 * * * \\
(0.0379)\end{array}$ \\
\hline Migration rates by age-education groups & $\begin{array}{c}\text { Main effects } \\
1970\end{array}$ & \multicolumn{3}{|c|}{ Interactions with year } \\
\hline 15-24 years; $0-4$ years of schooling & $\begin{array}{r}0.548 * * * \\
(0.0702)\end{array}$ & $\begin{array}{l}-0.0704 \\
(0.0924)\end{array}$ & $\begin{array}{c}0.144 \\
(0.100)\end{array}$ & $\begin{array}{l}-0.144 \\
(0.110)\end{array}$ \\
\hline $15-24$ years; $5-8$ years of schooling & $\begin{array}{c}0.311 * * * \\
(0.0919)\end{array}$ & $\begin{array}{l}0.0624 \\
(0.114)\end{array}$ & $\begin{array}{c}0.360 * * * \\
(0.125)\end{array}$ & $\begin{array}{c}-0.302 * * \\
(0.148)\end{array}$ \\
\hline 15-24 years; $9+$ years of schooling & $\begin{array}{c}0.440 * * * \\
(0.0911)\end{array}$ & $\begin{array}{l}0.0928 \\
(0.113)\end{array}$ & $\begin{array}{c}0.265^{* *} \\
(0.125) \\
\end{array}$ & $\begin{array}{l}-0.210 \\
(0.145)\end{array}$ \\
\hline $25-34$ years; $0-4$ years of schooling & $\begin{array}{c}0.416 * * * \\
(0.0536)\end{array}$ & $\begin{array}{c}0.108 \\
(0.0735)\end{array}$ & $\begin{array}{l}0.278 * * * \\
(0.0789)\end{array}$ & $\begin{array}{l}-0.0257 \\
(0.0797)\end{array}$ \\
\hline $25-34$ years; 5-8 years of schooling & $\begin{array}{c}0.291 * * * \\
(0.0643)\end{array}$ & $\begin{array}{c}0.139 \\
(0.0861)\end{array}$ & $\begin{array}{l}0.289 * * * \\
(0.0903)\end{array}$ & $\begin{array}{l}-0.165 * \\
(0.0963)\end{array}$ \\
\hline $25-34$ years; $9+$ years of schooling & $\begin{array}{c}0.393 * * * \\
(0.0679)\end{array}$ & $\begin{array}{l}-0.0554 \\
(0.0902)\end{array}$ & $\begin{array}{c}0.172 * \\
(0.0936) \\
\end{array}$ & $\begin{array}{l}-0.133 \\
(0.104)\end{array}$ \\
\hline 35-49 years; $0-4$ years of schooling & $\begin{array}{c}0.400 * * * \\
(0.0491)\end{array}$ & $\begin{array}{c}0.122^{*} \\
(0.0655)\end{array}$ & $\begin{array}{l}0.148 * * \\
(0.0688)\end{array}$ & $\begin{array}{l}-0.00933 \\
(0.0727)\end{array}$ \\
\hline 35-49 years; $5-8$ years of schooling & $\begin{array}{c}0.117 * \\
(0.0602)\end{array}$ & $\begin{array}{l}0.179 * * \\
(0.0787)\end{array}$ & $\begin{array}{l}0.348 * * * \\
(0.0820)\end{array}$ & $\begin{array}{c}0.117 \\
(0.0859)\end{array}$ \\
\hline $35-49$ years; $9+$ years of schooling & $\begin{array}{l}0.284 * * * \\
(0.0689)\end{array}$ & $\begin{array}{l}-0.0346 \\
(0.0871)\end{array}$ & $\begin{array}{c}0.115 \\
(0.0875)\end{array}$ & $\begin{array}{c}0.0362 \\
(0.0928)\end{array}$ \\
\hline 50-64 years; $0-4$ years of schooling & $\begin{array}{l}0.373 * * * \\
(0.0459)\end{array}$ & $\begin{array}{l}0.192 * * * \\
(0.0613)\end{array}$ & $\begin{array}{c}0.0583 \\
(0.0617)\end{array}$ & $\begin{array}{l}-0.0289 \\
(0.0630)\end{array}$ \\
\hline 50-64 years; $5-8$ years of schooling & $\begin{array}{c}0.0171 \\
(0.0647)\end{array}$ & $\begin{array}{c}0.0649 \\
(0.0851)\end{array}$ & $\begin{array}{c}0.112 \\
(0.0868)\end{array}$ & $\begin{array}{c}0.142 * \\
(0.0817)\end{array}$ \\
\hline 50-64 years; $9+$ years of schooling & $\begin{array}{c}0.0321 \\
(0.0808) \\
\end{array}$ & $\begin{array}{c}0.236 * * \\
(0.105) \\
\end{array}$ & $\begin{array}{c}0.115 \\
(0.103) \\
\end{array}$ & $\begin{array}{c}0.153 \\
(0.0989) \\
\end{array}$ \\
\hline $\begin{array}{l}\text { Number of observations } \\
\text { Number of groups }\end{array}$ & $\begin{array}{c}19,727 \\
2,008\end{array}$ & & & \\
\hline Fraction of variance due to area*time fixed effects & 0.8069 & & & \\
\hline $\begin{array}{l}\mathrm{F}(92 ; 17,627): \text { all coefficients }=0 \\
\mathrm{~F}(2,007 ; 17,627): \text { area*time fixed effects }=0\end{array}$ & $\begin{array}{l}2,776.41 * * * \\
21.63 * * *\end{array}$ & & & \\
\hline
\end{tabular}


Table 4. Fixed-effects estimates of age-education indicators and migration rates by age-education groups (less than five years in the municipality of residence) on the logarithm of mean real monthly earnings from primary occupation ${ }^{1}$ (dependent variable), Brazil, 1970-2000.

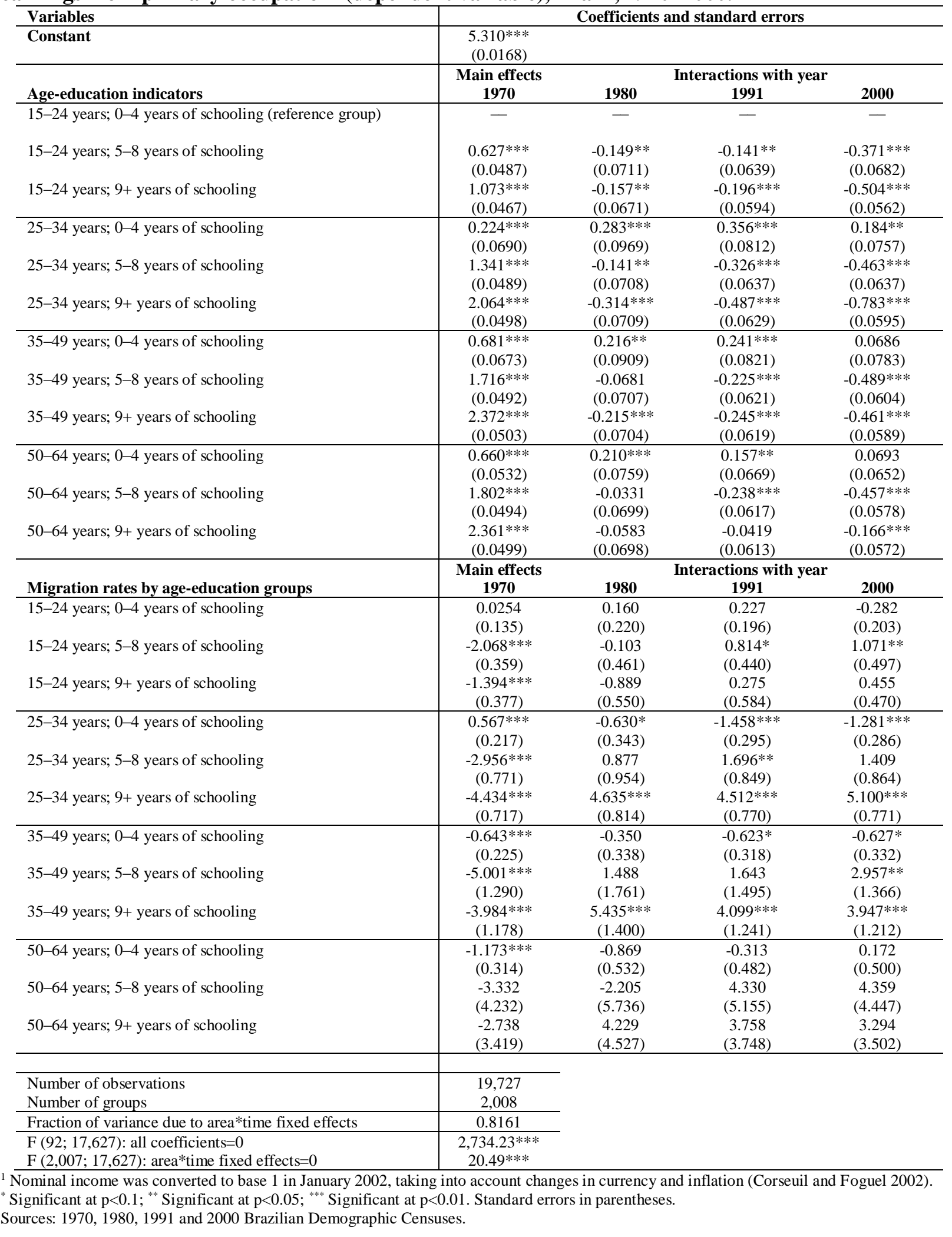


Table 5. Effects of migration rates by age-education groups (elasticities) on mean real monthly earnings from primary occupation ${ }^{+}$(dependent variable), based in Equation (1) for born in a different state (Table 3) and less than five years in the municipality of residence (Table 4), using the national migration rates (Table 2), Brazil, 1970-2000.

\begin{tabular}{|c|c|c|c|c|c|c|c|c|}
\hline \multirow{2}{*}{$\begin{array}{l}\text { Age-education } \\
\text { groups }\end{array}$} & \multicolumn{4}{|c|}{ Born in a different state } & \multicolumn{4}{|c|}{$\begin{array}{c}\text { Less than five years } \\
\text { in the municipality of residence }\end{array}$} \\
\hline & 1970 & 1980 & 1991 & 2000 & 1970 & 1980 & 1991 & 2000 \\
\hline $\begin{array}{c}15-24 \text { years } \\
0-4 \text { years of schooling }\end{array}$ & 0.109 & 0.100 & 0.128 & 0.072 & 0.008 & 0.046 & 0.044 & -0.026 \\
\hline $\begin{array}{c}15-24 \text { years } \\
5-8 \text { years of schooling }\end{array}$ & 0.055 & 0.056 & 0.097 & 0.001 & -0.110 & -0.225 & -0.175 & -0.141 \\
\hline $\begin{array}{c}15-24 \text { years } \\
9+\text { years of schooling }\end{array}$ & 0.085 & 0.073 & 0.091 & 0.026 & -0.044 & -0.135 & -0.077 & -0.104 \\
\hline $\begin{array}{c}25-34 \text { years } \\
0-4 \text { years of schooling }\end{array}$ & 0.104 & 0.137 & 0.167 & 0.098 & 0.129 & -0.012 & -0.132 & -0.072 \\
\hline $\begin{array}{l}25-34 \text { years } \\
5-8 \text { years of schooling }\end{array}$ & 0.074 & 0.100 & 0.116 & 0.026 & -0.067 & -0.090 & -0.098 & -0.137 \\
\hline $\begin{array}{c}25-34 \text { years } \\
9+\text { years of schooling }\end{array}$ & 0.102 & 0.073 & 0.098 & 0.044 & -0.117 & 0.012 & 0.007 & 0.072 \\
\hline $\begin{array}{c}35-49 \text { years } \\
0-4 \text { years of schooling }\end{array}$ & 0.106 & 0.144 & 0.146 & 0.105 & -0.121 & -0.148 & -0.174 & -0.139 \\
\hline $\begin{array}{c}35-49 \text { years } \\
5-8 \text { years of schooling }\end{array}$ & 0.035 & 0.077 & 0.111 & 0.055 & -0.059 & -0.058 & -0.095 & -0.114 \\
\hline $\begin{array}{c}35-49 \text { years } \\
9+\text { years of schooling }\end{array}$ & 0.090 & 0.066 & 0.090 & 0.065 & -0.052 & 0.033 & 0.006 & -0.003 \\
\hline $\begin{array}{c}50-64 \text { years } \\
0-4 \text { years of schooling }\end{array}$ & 0.106 & 0.158 & 0.118 & 0.099 & -0.096 & -0.137 & -0.097 & -0.062 \\
\hline $\begin{array}{c}50-64 \text { years } \\
5-8 \text { years of schooling }\end{array}$ & 0.006 & 0.025 & 0.034 & 0.042 & -0.011 & -0.023 & 0.006 & 0.013 \\
\hline $\begin{array}{c}50-64 \text { years } \\
9+\text { years of schooling }\end{array}$ & 0.012 & 0.083 & 0.039 & 0.047 & -0.009 & 0.007 & 0.009 & 0.011 \\
\hline
\end{tabular}

${ }^{1}$ Nominal income was converted to base 1 in January 2002, taking into account changes in currency and inflation (Corseuil and Foguel 2002). Sources: 1970, 1980, 1991 and 2000 Brazilian Demographic Censuses. 
Table 6. Effects of migration rates by age-education groups (elasticities) on mean real monthly earnings from primary occupation ${ }^{+}$(dependent variable), based in Equation (1) for each migration variable, using the national migration rates, Brazil, 1991-2000.

\begin{tabular}{|c|c|c|c|c|c|c|c|c|}
\hline \multirow[t]{2}{*}{$\begin{array}{l}\text { Age-education } \\
\text { groups }\end{array}$} & \multicolumn{2}{|c|}{$\begin{array}{c}\text { Born in a } \\
\text { different state }\end{array}$} & \multicolumn{2}{|c|}{$\begin{array}{l}\text { Less than five } \\
\text { years in the } \\
\text { municipality } \\
\text { of residence }\end{array}$} & \multicolumn{2}{|c|}{$\begin{array}{c}\text { Residence } \\
\text { five years } \\
\text { before Census }\end{array}$} & \multicolumn{2}{|c|}{$\begin{array}{c}\text { Adjusted } \\
\text { migration } \\
\text { (exogenous) }\end{array}$} \\
\hline & 1991 & 2000 & 1991 & 2000 & 1991 & 2000 & 1991 & 2000 \\
\hline $\begin{array}{c}15-24 \text { years } \\
0-4 \text { years of schooling }\end{array}$ & 0.128 & 0.072 & 0.044 & -0.026 & 0.046 & -0.028 & -0.053 & -0.063 \\
\hline $\begin{array}{c}15-24 \text { years } \\
5-8 \text { years of schooling }\end{array}$ & 0.097 & 0.001 & -0.175 & -0.141 & -0.164 & -0.137 & -0.172 & -0.062 \\
\hline $\begin{array}{c}15-24 \text { years } \\
9+\text { years of schooling }\end{array}$ & 0.091 & 0.026 & -0.077 & -0.104 & -0.079 & -0.077 & -0.270 & -0.058 \\
\hline $\begin{array}{c}25-34 \text { years } \\
0-4 \text { years of schooling }\end{array}$ & 0.167 & 0.098 & -0.132 & -0.072 & -0.137 & -0.079 & 0.006 & -0.019 \\
\hline $\begin{array}{c}25-34 \text { years } \\
5-8 \text { years of schooling }\end{array}$ & 0.116 & 0.026 & -0.098 & -0.137 & -0.088 & -0.127 & -0.035 & 0.038 \\
\hline $\begin{array}{c}25-34 \text { years } \\
9+\text { years of schooling }\end{array}$ & 0.098 & 0.044 & 0.007 & 0.072 & 0.017 & 0.090 & 0.025 & -0.066 \\
\hline $\begin{array}{c}35-49 \text { years } \\
0-4 \text { years of schooling }\end{array}$ & 0.146 & 0.106 & -0.174 & -0.139 & -0.175 & -0.129 & -0.011 & -0.058 \\
\hline $\begin{array}{c}35-49 \text { years } \\
5-8 \text { years of schooling }\end{array}$ & 0.111 & 0.055 & -0.095 & -0.114 & -0.084 & -0.097 & 0.181 & -0.041 \\
\hline $\begin{array}{c}35-49 \text { years } \\
9+\text { years of schooling }\end{array}$ & 0.090 & 0.065 & 0.006 & -0.003 & 0.009 & 0.003 & 0.281 & 0.006 \\
\hline $\begin{array}{c}50-64 \text { years } \\
0-4 \text { years of schooling }\end{array}$ & 0.118 & 0.099 & -0.097 & -0.062 & -0.108 & -0.056 & -0.024 & -0.028 \\
\hline $\begin{array}{c}50-64 \text { years } \\
5-8 \text { years of schooling }\end{array}$ & 0.034 & 0.043 & 0.006 & 0.013 & 0.003 & 0.011 & -0.257 & -0.003 \\
\hline $\begin{array}{c}50-64 \text { years } \\
9+\text { years of schooling }\end{array}$ & 0.039 & 0.047 & 0.009 & 0.011 & 0.010 & 0.012 & 0.028 & 0.142 \\
\hline
\end{tabular}


Table 7. Effects of migration rates by age-education groups (elasticities) on mean real monthly earnings from primary occupation ${ }^{+}$(dependent variable), based in Equation (2) for each migration variable, using the national migration rates, Brazil, 1991-2000.

\begin{tabular}{|c|c|c|c|c|c|c|c|c|}
\hline \multirow[t]{2}{*}{$\begin{array}{l}\text { Age-education } \\
\text { groups }\end{array}$} & \multicolumn{2}{|c|}{$\begin{array}{c}\text { Born in a } \\
\text { different state }\end{array}$} & \multicolumn{2}{|c|}{$\begin{array}{l}\text { Less than five } \\
\text { years in the } \\
\text { municipality } \\
\text { of residence }\end{array}$} & \multicolumn{2}{|c|}{$\begin{array}{c}\text { Residence } \\
\text { five years } \\
\text { before Census }\end{array}$} & \multicolumn{2}{|c|}{$\begin{array}{c}\text { Adjusted } \\
\text { migration } \\
\text { (exogenous) }\end{array}$} \\
\hline & 1991 & 2000 & 1991 & 2000 & 1991 & 2000 & 1991 & 2000 \\
\hline $\begin{array}{c}15-24 \text { years } \\
0-4 \text { years of schooling }\end{array}$ & 0.121 & 0.048 & 0.078 & 0.051 & 0.083 & 0.043 & -0.095 & -0.132 \\
\hline $\begin{array}{c}15-24 \text { years } \\
5-8 \text { years of schooling }\end{array}$ & 0.103 & -0.007 & -0.034 & -0.145 & -0.035 & -0.157 & -0.224 & -0.222 \\
\hline $\begin{array}{c}15-24 \text { years } \\
9+\text { years of schooling }\end{array}$ & 0.080 & 0.017 & 0.133 & 0.099 & 0.106 & 0.134 & -0.203 & -0.012 \\
\hline $\begin{array}{c}25-34 \text { years } \\
0-4 \text { years of schooling }\end{array}$ & 0.136 & 0.068 & -0.057 & 0.012 & -0.058 & 0.000 & -0.087 & -0.100 \\
\hline $\begin{array}{c}25-34 \text { years } \\
5-8 \text { years of schooling }\end{array}$ & 0.120 & 0.046 & 0.092 & 0.034 & 0.082 & 0.021 & -0.141 & -0.114 \\
\hline $\begin{array}{c}25-34 \text { years } \\
9+\text { years of schooling }\end{array}$ & 0.087 & 0.032 & 0.041 & 0.168 & 0.051 & 0.178 & 0.005 & -0.117 \\
\hline $\begin{array}{c}35-49 \text { years } \\
0-4 \text { years of schooling }\end{array}$ & 0.113 & 0.068 & -0.082 & -0.026 & -0.083 & -0.016 & -0.120 & -0.170 \\
\hline $\begin{array}{c}35-49 \text { years } \\
5-8 \text { years of schooling }\end{array}$ & 0.109 & 0.061 & 0.012 & 0.083 & 0.013 & 0.085 & 0.139 & -0.257 \\
\hline $\begin{array}{c}35-49 \text { years } \\
9+\text { years of schooling }\end{array}$ & 0.078 & 0.055 & 0.059 & 0.021 & 0.054 & 0.024 & 0.274 & -0.041 \\
\hline $\begin{array}{c}50-64 \text { years } \\
0-4 \text { years of schooling }\end{array}$ & 0.090 & 0.074 & -0.074 & 0.004 & -0.089 & 0.010 & -0.100 & -0.114 \\
\hline $\begin{array}{c}50-64 \text { years } \\
5-8 \text { years of schooling }\end{array}$ & 0.014 & 0.031 & 0.057 & 0.036 & 0.048 & 0.029 & -0.341 & -0.091 \\
\hline $\begin{array}{c}50-64 \text { years } \\
9+\text { years of schooling }\end{array}$ & 0.029 & 0.039 & 0.016 & -0.021 & 0.016 & -0.013 & -0.012 & 0.074 \\
\hline
\end{tabular}

